\title{
The Mysterious Origins of Lawrence of Arabia
}

\author{
By Ron Paquet \\ Spring 1994 Issue of KINEMA
}

THE THIRTIETH ANNIVERSARY OF DAVID LEAN'S CLASSIC FILM, Lawrence of Arabia, in 1992, brought with it the restored print and the publication of several books and the screenplay, together with a number of other celebrations befitting this impressive picture and the work of its late director. The screenplay was written by Robert Bolt based on a previous script by Michael Wilson. Many previous attempts had been made over the years to bring Lawrence to the screen. One of the earliest was written by John Monk Saunders, the American screenwriter who wrote Wings and a succession of dramas dealing with WWI. This is how he envisioned scenes later immortalized by Wilson and Bolt.

During the two years of the World War in which Lawrence of Arabia was engaged in the revolt of the Arabs against the Turks he make innumerable excursions into the desert, performing myriad exploits and met countless characters. His journeys present a bewildering tracery of comings and goings. He and his followers appear and disappear like vapour across the shifting sands.

It is not our intention to present a faithful chronicle of his campaigns, not an ordered account of his adventures, nor a perfect portrait of his friends and enemies. It is known, for instance, that he blew up seventy-nine trains. How is it possible, within the compass of the picture to depict each demolition in turn?

It is with the drama of Lawrence's career that we are concerned, not the dry bones of historical fact. The necessities of the screen require choice of incident, selection of character, and compression of time. The scattering of places, men, and action must be gathered together and fashioned into a complete unity. Only then is it possible to measure the character of Lawrence against his background, to understand the significance of his efforts and their importance to the world.

Since it is impossible to identify all of the characters who travelled with Lawrence along the road to Damascus we must identify none of them, Lawrence himself already paid homage to them in his writings.

John Monk Saunders

On December 12, 1934 an agreement was signed between Alexander Korda's London Film Productions Ltd. and the trustees of T. E. Lawrence's Revolt in the Desert, Lieutenant-Colonel Robert Vere Buxton and the Honourable Edward Eliot, for "...all the motion picture rights throughout the world ... for the purpose of producing the said motion picture and to project, transmit or otherwise reproduce the said work pictorially and or audibly by the art of cinematography or any process similar thereto including the right to exhibit the said motion picture by television or any other process of instant transmission now known or hereafter to be devised and ... exhibit the said motion picture in all territories throughout the world."

The script was to be written by John Monk Saunders. The price was 3,000 plus 5 per cent of the net receipts. Other provisions insisted upon historical accuracy and "that no female characters otherwise than as members of crowds or the like supernumaries shall be introduced into the said picture." Also that "if any dispute between the company and the trustees as to whether there has been any and what serious variation or deviation from the approved scenario shall be referred to the decision of the Rt. Hon. Winston Churchill."

Further agreement in August 1937 allowed the title to be changed to Lawrence of Arabia and that Col. Walter Stirling would now "agree to and approve in writing on behalf of the trustees any alterations or deviations from the said scenario."

Saunders completed his screenplay on September 28, 1935 and produced a second draft shortly thereafter. In style, it shares many of the same characteristics as The Lives of a Bengal Lancer (1935), Four Feathers (1939), and Gunga Din (1939), including simplistic dialogue, romantic ideals, and abundant action.

Briefly, the scenario reads like this: Turks hang Arab conspirators; Arabs revolt and attack Medina and fail; Turks destroy Arab village as object lesson; Arab revolt flounders; Lawrence arrives on scene; Lawrence leads 
Arabs in attacks on Turks; eventually Arabs take Damascus; Lawrence is content. The cast of characters includes Prince Feisal, Auda Abu Tayi, Farraj and Daud, and General Allenby. Also Jemal Pasha the Turkish Viceroy of Syria and Palestine, Sherif Ali, Abdulla, and Lewis and Stokes.

The entire story takes place in Arabia although in the second draft it begins with the news of Lawrence's death from a motorcycle accident and then goes into flashback.

On reading the screenplay it became evident that much of the action of the famous Lawrence of Arabia (directed by David Lean and scripted by Robert Bolt, 1962) had been preconceived by Saunders. There are numerous parallels between the two scenarios which is surprising given that they were written twenty-five years apart. One can only surmise that when Sam Spiegel acquired the film rights from Alexander Korda in 1959 that he also acquired this (and other) screenplays as part of the package and that he handed this over to Michael Wilson, who retained and improved these scenes and incorporated them into his own screenplay. The following examples provide sufficient illustration.

\section{SCRIPT EXCERPT 1 -- Lawrence makes his appearance:}

LONG SHOT from Feisal's angle: Appearing over a distant ridge and riding down the valley on a camel, comes a strange figure wearing English field uniform and Arabian headdress. There is something inevitable about the stranger's approach, as if he were guided by a star.

MEDIUM CLOSE SHOT: The stranger dismounts and goes directly to Feisal. For a moment the two stand looking at one another -- both seem to realise that this is an historic, a fateful encounter.

Feisal's room at Hamra: The semi darkness of the room hides many silent figures who gaze steadily at Lawrence. Feisal is sitting on his carpet near the door. He stares down at his hands which are twisting slowly about his cigarette and coffee.

FEISAL (softly): How did you find the journey?

LAWRENCE: The heat was oppressive.

FEISAL: But you rode fast for the season.

LAWRENCE: I was provided with good camels.

FEISAL: And how do you like our place here at Wadi Safra?

LAWRENCE (after a significant pause): Well; but it is far from Damascus.

FEISAL (looking directly into Lawrence's eyes): Praise be to God there are Turks nearer us than that.

LAWRENCE: You are determined upon revolt?

FEISAL: There can no longer be any question of submission to the Turks.

LAWRENCE (quickly): And that he must be swept out of Holy Arabia?

FEISAL (continuing): But you find us in despair.

LAWRENCE: You have rifles?

FEISAL (scornfully): Japanese rifles, yes. Broken and rusty. The barrels are so foul they burst in our faces when we fire them.

LAWRENCE: Ammunition?

FEISAL: Not enough bullets to keep the army in gazelle meat.

LAWRENCE: Provisions?

FEISAL (bitterly): We live off the land. Locusts and wild honey. (in a sudden dramatic outburst): My men are not afraid of bullets! Nor indeed of death! But they believe that bursting shells, are as fatal as they shound [sic]. The sound of cannon sends every man to cover. We excel in hand-to-hand fighting but we cannot come to grips with the enemy! What we need is artillery! Artillery! Artillery! 
LAWRENCE (quietly): What are your plans?

FEISAL: Until Medina falls I am tied down here, dancing to Fakhri Pasha's tune.

LAWRENCE (quietly): If you will turn away from Medina...

FEISAL: From Medina?

LAWRENCE: And turn your face towards Damascus...

FEISAL: Damascus?

LAWRENCE (rising to his feet): You will find stores and arms waiting for you at Yenbo.

Without further words Lawrence goes to the doorway, turns and gives Feisal a farewell salute.

FEISAL: Peace be with you.

Lawrence turns and goes out.

MEDIUM CLOSE SHOT: Feisal and group watching Lawrence's departure.

LONG SHOT: Lawrence departing into the desert as mysteriously as he arrived.

CLOSE SHOT: Group at doorway.

TRIBESMEN: Who is this Lord who speaks our tongue, understands our minds and offers us help?

FEISAL: I do not know, but I shall follow him to Yenbo.

[One is immediately struck by the similarity of this scene with the appearance of Sherif Ali at the well in Bolt's script: the mysterious rider, the clipped dialogue, the self-assurance of the mysterious figure.]

SCRIPT EXCERPT 2 -- In the Bolt/Lean scenario, Gasim is found guilt of murder and must be executed. In Saunders' version it is Hamed the Moor:

SULEIMAN: As a relative of the murdered man I demand blood for blood.

LAWRENCE: Blood must not be shed.

SULEIMAN: It is the law of the desert, Lord.

CLOSE SHOT: Hamed the Moor falls grovelling on the ground, babbling his prayers.

CLOSE SHOT: Lawrence. He draws his revolver from the sleeve of his cloak, raises it and fires.

MEDIUM CLOSE SHOT, ravine: The Moor, shot through the chest, screams in mortal fear, falls forward and threshes about amongst the weeds in the canyon. Lawrence brushes his shaking hand across his eyes as if to blot out the scene. Once more he raises his revolver and fires. But the cries of the Moor do not cease. Lawrence raises his revolver for the third time, steps forward -- and fires. Silence reigns in the canyon. The camera follows Lawrence as he returns to the waiting Tribesmen.

SULEIMAN: The Lord took the burden of punishment upon himself.

TRIBESMEN: It is right. The Lord is not qualified for a blood-feud. He is a stranger without relatives. No revenge will come upon his followers.

FADE OUT

SCRIPT EXCERPT 3 -- The appearance of the imps, Farraj and Daud, who are caught, punished and beg to join Lawrence's service.

MEDIUM CLOSE SHOT: They salute Lawrence.

DAUD: We are for your service, Lord.

LAWRENCE: I have no need for you, besides after your beating I doubt you can ride.

FARRAJ: But we have just ridden here, bare-backed. 
LAWRENCE: I am a simple man, and I dislike servants about me.

FERRAJ (pleading): You must have men to guard you, Lord, and we are willing to follow you for company and out of gratitude.

LAWRENCE: I am sorry, but your services are of no use to me.

FERRAJ: Speak to the Lord on our behalf.

NASIR: It is possible that they may be of service to you.

LAWRENCE (turning to boys): On one condition, then.

DAUD AND FERRAJ (in chorus): What is it the condition, Lord?

LAWRENCE: No more tricks --

With joyous cries of "We Promise!" they kiss Lawrence's hand and run off.

SCRIPT EXCERPT 4 -- The first meeting between Allenby and Lawrence:

INTERIOR ALLENBY'S OFFICE CAIRO: The contours of Allenby's head and shoulders loom largely in the foreground. Physically he is three times the size of the little bare-footed, silk-skirted man sitting opposite.

ALLENBY: ... and exactly what are you asking for?

LAWRENCE: A storeship to carry food to Akaba and bring back Turkish prisoners.

ALLENBY: That's not impossible to arrange.

LAWRENCE: I shall require rifles, guns, airplanes, armoured cars, high explosives ...

ALLENBY (ironically): Anything else?

LAWRENCE (continuing smoothly): Two hundred thousand pounds ...

ALLENBY: Two hundred THOUSAND ...

LAWRENCE (evenly): ... in gold. And a battleship to stand guard at Akaba. (in answer to Allenby's apparent look of astonishment): The flagship preferably.

ALLENBY: Just as a matter of interest. Why the flagship?

LAWRENCE: In Arabia ships are admired by the number of funnels. A four-stacker will impress the Bedouins.

ALLENBY (terminating the interview): I will do what I can for you.

SCRIPT EXCERPT 5 -- Lawrence is caught in Deraa and is beaten:

MEDIUM CLOSE SHOT: As the two figures pass the machines a voice calls out after them:

VOICE: Come here!

The two figures proceed as if they did not hear the command.

VOICE: Come back here!

Still the two figures continue without turning.

MEDIUM LONG SHOT: A Turkish Sergeant running across the field and catching up with the peasants.

MEDIUM CLOSE SHOT: The Sergeant seizes the smaller man by the arm, turns him roughly about and says:

SERGEANT: The Bey wants you.

MEDIUM CLOSE SHOT: The Sergeant calls Lawrence to attention in front of the Turkish officer.

TURKISH OFFICER: What are you? 


\section{LAWRENCE: Circassian.}

TURKISH OFFICER (sharply): Deserter?

LAWRENCE: But we Circassians have no military service.

The moment the guards enter with Lawrence he [the Bey] waves them out. As they close the door the Bey speaks to Lawrence.

BEY: Circassian?

\section{LAWRENCE: Yes.}

BEY (abruptly): I need an Orderly.

The Bey reaches out his hand and rests it upon Lawrence's shoulder.

Instantly Lawrence recoils.

BEY: What's this?

He advances another step and again attempts to put his hands on Lawrence. Lawrence pushes him off balance.

BEY: You will beg my pardon!

LAWRENCE (between his teeth): Never.

The Bey takes off his slipper and strikes Lawrence repeatedly in the face while the Corporal holds Lawrence's head back by seizing his hair in his hands. Lawrence does not flinch. The Bey draws the Sentry's bayonet from his scabbard and cuts away the upper part of Lawrence's clothes.

For a moment the Bey stares at he observes the bullet marks on Lawrence's naked torso, then he works the point of the bayonet into the flesh over Lawrence's ribs and gives the blade a half-turn. The blood flows down Lawrence's side.

BEY: Are you ready to apologize?

LAWRENCE: (steadily): No.

FULL SHOT, Guard Room - Night: The four soldiers stretch the half-clad figure of Lawrence, face downwards, over a guard-bench, and begin to pummel him unmercifully.

CLOSE SHOT: Circassian whip. It is made of supple black hide, rounded and tapering from the thickness of a thumb at the grip, which is wrapped in silver wire, down to a hard point, finer than a pencil.

MEDIUM CLOSE SHOT: The Corporal cuts the air with whistling slashes. His [Lawrence's] face becomes distorted with pain. He is trying to hold on to his sanity by keeping track of the number of blows.

MEDIUM CLOSE SHOT: The Corporal wielding the whip with all his power since he cannot bring a cry of pain from his victim.

MEDIUM LONG SHOT, LAWRENCE: The sentry kicks Lawrence off the bench with his nailed boot, on to the floor. Lawrence, broken, gasping, dazed and semi-conscious, lies on the floor, his body jerking and twisting with pain. For a moment he is left alone.

\section{SCRIPT EXCERPT 6 -- The death of Farraj:}

CLOSE SHOT: Lawrence and Farraj.

Lawrence kneels beside Farraj and examines the wound.

Two of the bodyguard ride up and dismount. They run to Farraj's side.

MEDIUM CLOSE SHOT: The bodyguard take one look at the wound and shake their heads. The bullet has smashed through Farraj's body and broken his spine. Lawrence covers over the wound, turns his head and looks up at them.

ABDULLA (softly): He has only a few hours to live. 
LAWRENCE: Then help me to move him.

ABDULLA (to Lawrence): Lord, we cannot leave him for the Turks to torture.

LAWRENCE (turning to his bodyguard): Get ready to move off.

TWO-SHOT: Lawrence and Farraj. Lawrence kneels down beside Farraj. His right hand steals into the folds of his robes where he carries the pistol. Tenderly he lifts Farraj's head. Farraj opens his eyes and clutches Lawrence with his hands. For an instant the old familiar gleam of mischief appears in his eyes as he says softly to Lawrence:

FARRAJ: Daud will be angry with you.

LAWRENCE (gently): Salute him from me.

FERRAJ (as he closes his eyes): God will give you Peace.

By now machine gun bullets are stinging the air above Lawrence's head.

There is a muffled report from beneath the folds of Lawrence's cloak.

Farraj's body jumps and then lies quite still in Lawrence's arms.

Lawrence eases Farraj's head gently to earth and covers his face with his robes.

LONG SHOT: Lawrence rises to his feet, turns his back on the Turks and disappears over the embankment where his camel is hobbled.

FADE OUT

[Virtually identical to Bolt/Lean script.]

SCRIPT EXCERPT 7 -- The destroyed village, the death of Tallal, and the massacre of the Turks:

MEDIUM CLOSE SHOT: Troop riding along road toward village.

Now the roadside is littered with the bodies of old men, women and children. As the troops approach the low mud walls of the village a scene of death and horror meets them.

MEDIUM LONG SHOT: Across the walls, sheep-folds, lie the naked, white bodies of women, nailed there by Turkish bayonets. The smoke from the burning houses casts a merciful veil over the atrocities.

CLOSE SHOT: Lawrence. What he has seen has changed his face into a merciless mask. His eyes narrow into slits and his jaws are fixed.

LONG SHOT: Retreating Turkish column from Lawrence's angle.

MEDIUM CLOSE SHOT: Lawrence. Lawrence starts to ride to Tallal's side, but Auda catches his rein and stops him.

AUDA: Let him be.

CLOSE SHOT TALLAL: Very slowly he draws his headcloth about his face. Suddenly he seems to take hold of himself, drives his stirrups into the mares flanks and...

MEDIUM LONG SHOT: Tallal, bending low and swaying in the saddle, his rifle at his side, gallops headlong right at the main body of the enemy. In his long ride down a gentle slope and across a hollow, the drumming of the hoofs of his mare echoes in the valley.

MEDIUM CLOSE SHOT: Lawrence and camelmen. Lawrence, Auda and the troops have stopped shooting and sit [on] their mounts like stone -- watching the death ride.

MEDIUM CLOSE SHOT -- TURKS: The Turks, too, spellbound, have stopped shooting and gaze at the oncoming rider. 
MEDIUM CLOSE SHOT -- TALLAL: When but a few lengths from the enemy the Arab Chieftain raises himself in his saddle and cries out his war-cry.

TALLAL: TALLAL! TALLAL!

MEDIUM CLOSE SHOT: Turkish Rearguard. Rifles and machine guns crash out.

MEDIUM LONG SHOT -- TALLAL: Riddled through and through with bullets, Tallal's mare goes down, and the Arab warrior falls dead amongst the Turkish lance-points.

LAWRENCE (turning about in his saddle and giving this order for the first and last time in the Arab war): No prisoners.

MEDIUM CLOSE SHOT: As the word passes along the line from Arab mouth to Arab mouth -- lips twitching with fury and vengeance.

ARABS: No prisoners.

LONG SHOT: Lawrence leading his camelmen in a rocketing charge down the valley against the Turks.

LONG SHOT: Turks splitting up into three sections and scattering into the desert.

FLASH: Turk dropping his rifle and holding up his hands, babbling for mercy. Auda rides him down, whipping three bullets into his chest with his automatic.

FLASH: Turkish soldier on his knees, begging for his life. He disappears under the crashing hoofs of Auda's horsemen.

LONG SHOT: EXT. PLAIN. SUNSET: The plain is scattered with dead men, animals, horses, and an assortment of discarded rifles, machine guns, field pieces and gun carriages.

There are other scenes as well: an Arab attack of massed camels and horses against Turkish positions and the blowing up and looting of a Turkish train.

Saunders wrote several other interesting scenes not incorporated into the Lean film, such as:

i) A scene with Abdulla:

FULL SHOT, INTERIOR TENT: Abdulla, surrounded by a bevy of silk-clad followers is playing Chess. His manner is preoccupied and he does not appear to be at all impressed by the arrival of his visitor, nor the dispatches which he carries. In fact he proceeds with his game throughout the interview.

LAWRENCE: Your brother Feisal asked me to deliver these dispatches to you.

ABDULLA: Thank you.

LAWRENCE: The position is somewhat serious.

ABDULLA: In what way?

LAWRENCE: The Turks intend to evacuate Medina.

Abdulla betrays a polite interest in this piece of news.

ABDULLA: Do they indeed? And how are things going in the Hejaz?

LAWRENCE: Well.

ABDULLA: They should. If Great Britain keeps her promise to my father.

LAWRENCE: It is important that the Railway from Medina is blocked. It is Feisal's opinion that you could be of service in this direction.

ABDULLA: I don't take part in raids. It is my opinion that this is Feisal's business.

LAWRENCE: Then he cannot expect any action from you?

ABDULLA (pettishly): I came here to please my brother and here I will remain. 
ii) a scene with Auda:

CLOSE SHOT, AUDA: He has sunk his teeth into a leg of sheep, which he holds in both hands when suddenly he casts it down, spits and cries:

AUDA: God forbid!

FULL SHOT: Auda scrambles to his feet and rushes out of the tent. While the others look at one another in surprise, a loud hammering is heard outside. Lawrence gets to his feet and goes out.

MEDIUM CLOSE SHOT, EXTERIOR TENT: Auda -- in a furious rage, is bending over a rock, pounding his false teeth into fragments with a stone.

He looks up at Lawrence and by way of explanation announces:

AUDA: Auda has forgotten! Jemal Pasha gave Auda these! Auda was eating his Lord's meat with Turkish teeth!

FADE OUT

iii) Massacre of Turkish prisoners:

MEDIUM CLOSE SHOT: Lawrence riding through plain toward detachment of 200 Turkish prisoners escorted by Arabs.

LAWRENCE (to Abdulla): Set up your automatics.

MEDIUM CLOSE SHOT: Three of Lawrence's machine gunners dismount, unload their Lewis guns, and set them up in front of the cowering Turks.

MEDIUM CLOSE SHOT: THE CAMERA SEES THE SCENE from behind and through the sights of a Lewis automatic machine gun.

As the gunners open fire and the muzzle of the gun is traversed from side to side like a hose, the two hundred grovelling prisoners are cut down as if by an invisible scythe.

iv) Closing scene:

LONG SHOT: As the tumult and shouting slowly die away we see the gilded towers and the minarets of the City of Damascus bathed in the light of the late afternoon sun; looking impossibly beautiful and unreal. As twilight comes down upon the city the Muezzins send out their call to prayer through the night. One, with a ringing voice of special quality, cries from a nearby Mosque.

MUEZZIN: God alone is great: I testify there are no Gods but God: and Mohammed is His Prophet.

CLOSE SHOT: Lawrence. He is standing alone on the balcony of a house in Damascus. He is clad in his Arab head-dress and his immaculate white robes, with the golden dagger of Mecca in his girdle. He stands lonely and straight as a pillar, looking out over the darkening City.

\section{FADE OUT}

But Lawrence then changed his mind and did not want the film made during his lifetime. His death in May 1935 allowed the trustees to approve the project. Another screenplay was produced by Miles Malleson and it is probably this screenplay that was approved by the trustees on December 29, 1936.

The screenplay fell under the close scrutiny of the British Board of Censors who would not pass it because of strong Turkish objections. Continued protests by the Turkish government, unrest in Palestine where the film was to be shot, and financial difficulties finally forced Korda to abandon the project.

\section{Author Information}

Ron PAQUET is a well-known collector and archivist of David Lean's film career. He has been involved as consultant on several projects, including the first complete retrospective of David Lean's films for the Ontario 
Film Institute in 1986, Stephan Silverman's book David Lean, Robert Harris' restoration of Lawrence of Arabia, and the forthcoming biography of David Lean by Kevin Brownlow. 